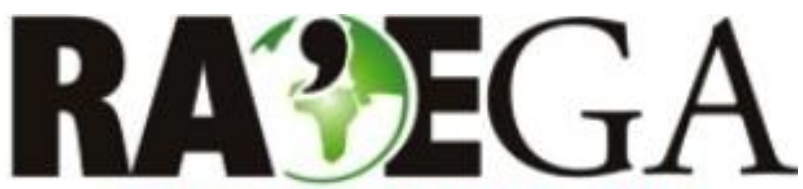

O ESPACO GEOGRÁFICO EM ANÁLISE

\title{
MAPA DE NIVELAMENTO DE TOPOS NA ANÁLISE DA EVOLUÇÃO GEOMORFOLÓGICA DA BACIA HIDROGRÁFICA DO RIBEIRÃ̃O SANTO INÁCIO, ESTADO DO PARANÁ.
}

\section{SUMMIT LEVEL MAP IN THE GEOMORPHOLOGICAL EVOLUTION ANALYSIS OF THE SANTO INÁCIO CREEK HYDROGRAPHIC BASIN, PARANÁ STATE}

\author{
Edison Fortes \\ Professor da Universidade Estadual de Maringá (UEM) \\ Departamento de Geografia \\ Maringá, $P R$ \\ e-mail: edison-fortes@hotmail.com
}

Doutorando em Geografia pela Universidade Federal de Minas Gerais (UFMG)

Departamento de Geografia

Belo Horizonte, MG

e-mail: michael.sordi@gmail.com

\section{Recebido em: 21/12/2012}

Aceito em: 18/03/2014

\section{Resumo}

Este trabalho trata da aplicação de mapas de nivelamento de topos na bacia hidrográfica do ribeirão Santo Inácio, tributário do rio Paranapanema, situado no extremo norte central paranaense, para análise dos elementos morfoestruturais que condicionaram a evolução do relevo. Para realização desse trabalho foram utilizadas como base as cartas topográficas de escala 1: 50.000. Os mapas de Nivelamento de Topos permitem preencher seletivamente os vales de maneira a reconstituir 0 paleorelevo. O modelado do relevo da bacia hidrográfica do ribeirão Santo Inácio teve sua evolução controlada por altos e baixos estruturais, que condicionaram processos geoquímicos e influenciaram a organização da cobertura pedológica. $O$ rompimento dos altos estruturais permitiu a ligação de zonas deprimidas, até então isoladas, formando corredores alongados que constituem atualmente o fundo dos 
vales da bacia hidrográfica do ribeirão Santo Inácio. Processos de perda isovolumétrica levaram a um rebaixamento e aplanamento do relevo, comandados por uma frente de alteração em íntima associação com a erosão remontante. O nível de base representado pelo rio Paranapanema teve maior importância a partir do momento que as zonas deprimidas estavam completamente definidas. A existência de remanescentes de superfícies de aplainamento não pôde ser comprovada, apontando-se para uma evolução do modelado de relevo local por uma combinação de processos geoquímicos condicionados por fatores morfoestruturais locais.

Palavras-chave: Mapa de Nivelamento de Topos; Ribeirão Santo Inácio; Evolução Do Relevo.

\begin{abstract}
This work deals with the application of summit level maps from Santo Inácio creek hydrographic basin, tributary of Paranapanema River, situated in the paranaense far north central, for analysis of the morphoestructural elements that conditioned the relief evolution. To realize this work topographic letters of 1:50.000 scale were used as base. The summit level maps allows to fill selectively the valleys in order to reconstitute the paleorelief. The modeling relief in Santo Inácio creek basin had its evolution driven by structural ups and downs that conditioned geochemical process and influenced the pedological cover organization. The severing of structural highs allowed the connection of depressed areas, until then isolated, forming elongated corridors which currently constitute the bottom of the valleys of hydrographic basin of the Santo Inácio creek. Process of isovolumetric losses led to a lowering and planning of relief, commanded by an alteration front in close relation to headwater erosion. The base level represented by the Paranapanema River had bigger importance from the moment that the depressed areas were completely defined. The existence of planation surfaces remainings could not be proved, pointing to an evolution of the local shape relief by a combination of geochemical process conditioned by local morfoestructural factors.
\end{abstract}

Keywords: Summit Level Map; Santo Inácio River; Relief Evolution.

\title{
INTRODUÇÃO
}

O estudo do Cenozóico brasileiro, no qual pode ser incluído também o Estado do Paraná, tem sido feito a partir de trabalhos ambientais, destancando-se os estudos geomorfológicos e estratigráficos. Estes estudos baseavam-se, principalmente, na associação de superfícies de aplainamento e seus depósitos correlativos, e o reconhecimento dos paleoclimas responsáveis pelos processos 
atuantes (DE MARTONNE, 1943, 1944; KING, 1956; BIGARELLA e AB'SABER, 1964; BIGARELLA e MOUSINHO, 1965; AB'SABER, 1977, entre outros).

Para os autores supracitados o relevo brasileiro teve sua evolução associada aos processos erosivos/deposicionais ocorridos a partir do Terciário. $\mathrm{O}$ intervalo Terciário-Pleistoceno corresponderia ao último grande período modelador do relevo, sobre o qual se instalaram os modelados de cada compartimento geomorfológico.

A ruptura continental mesozoica, bem como os processos pós-cretáceos subsequentes, tiveram grande influência na estruturação e na compartimentação do relevo paranaense. No Palegeno, os processos epirogenéticos soergueram as bordas da Bacia Sedimentar do Paraná. A epirogênese permitiu a aceleração dos processos erosivos junto as frentes de Cuestas e levou à formação dos planaltos denominados de Primeiro e Segundo Planalto Paranaense por Maack (1948).

Paisani et al. (2008) a partir de estudos de superfícies aplainadas do sudoeste do Paraná e oeste catarinense, sobre a borda do planalto basáltico, identificaram oito remanescentes de superfícies aplainadas organizadas em escadaria de leste para oeste, com até três níveis embutidos e uma superfície em elaboração, esta última sob cotas inferiores a $600 \mathrm{~m}$. Os autores atribuíram o escalonamento das superfícies aplainadas a fatores tectônicos associados a processos de etch, com rebaixamento por perda isovolumétrica do substrato em clima subtropical úmido.

No presente trabalho o mapa de nivelamento de topos é empregado para análise da evolução do relevo. A técnica de nivelamento de topos consiste na reconstituição do paleorrelevo a partir de dados altimétricos atuais. A técnica inicialmente desenvolvida por geólogos e geomorfólogos japoneses (HUZITA e KASAMA, 1977 apud MOTOKI et al., 2008), foi divulgada, no Brasil, por MOTOKI et al. (2008), com a denominação de mapas de Seppômen. O principal objetivo é reconstituir o paleorrelevo da bacia hidrográfica do ribeirão Santo Inácio, a partir do mapa de nivelamento de topos. Além disso, visa estabelecer correlação do paleorrelevo com aspectos morfoclimáticos regionais e geoestruturais; analisar as influências estruturais e morfoclimáticas na configuração e evolução da rede 
Mapa de nivelamento de topos na análise da evolução geomorfológica da bacia hidrográfica do ribeirão Santo Inácio, Estado do Paraná

hidrografia, investigar o comportamento geoquímico dos volumes pedológicos, a partir de trabalhos já desenvolvidos no noroeste paranaense, e propor um modelo teórico de evolução do modelado do relevo da bacia hidrográfica.

\section{ÁREA, MATERIAIS E MÉTODOS}

A bacia hidrográfica do ribeirão Santo Inácio está localizada no extremo norte do Estado do Paraná, entre as coordenadas 22037'24.56" e 22057'33.76" de

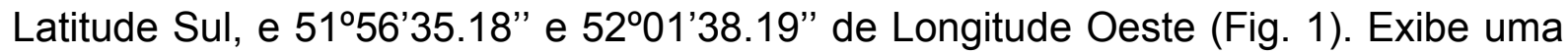
extensão de aproximadamente $25 \mathrm{~km}$ e uma área de $390,92 \mathrm{~km}^{2}$.

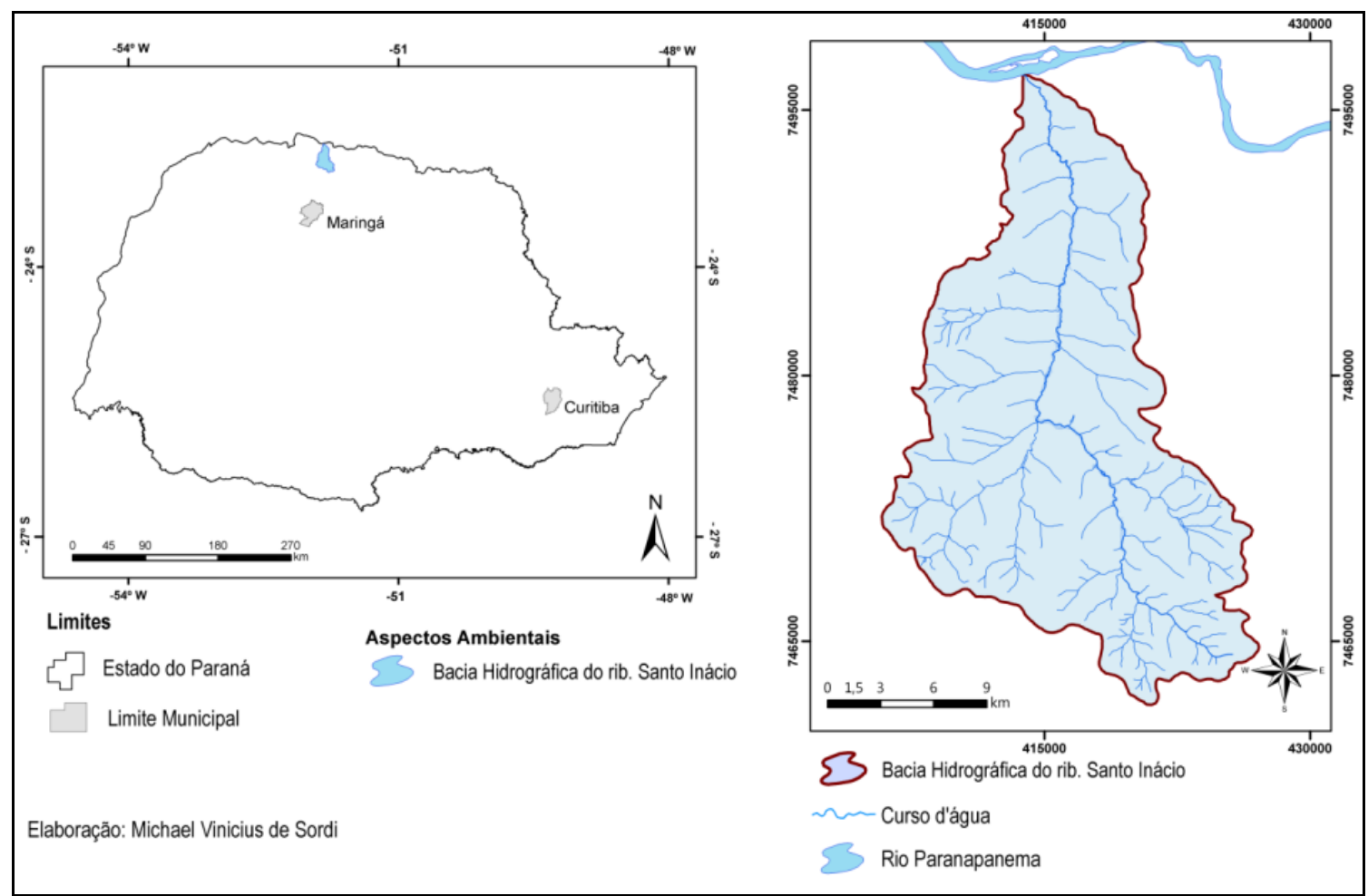

Figura 1: Localização da bacia hidrográfica do ribeirão Santo Inácio.

A área encontra-se inserida no Terceiro Planalto Paranaense, também denominado Planalto de Apucarana, conforme designação de Maack (1968), caracterizado pela presença de pequenos espigões, que constituem divisores de água secundários, e suaves colinas e platôs.

A base de dados foram as Cartas Topográficas de Santo Inácio (Folha SF22-Y-B-V-1), de Colorado (Folha SF-22-Y-B-V-3) e de Centenário do Sul (Folha SF- 
22-Y-B-V-4), todas na escala 1:50.000, editadas pelo IBGE. O processamento dos dados topográficos se deu através dos softwares SPRING 5.1.2 e SURFER 8.0.

Com base nas informações obtidas foram elaborados os mapas de nivelamento de topos, bem como Modelos Numéricos do Terreno do modelado atual. O mapa de nivelamento de topos constitui-se em uma técnica cartográfica de preenchimento de vales, buscando a reconstituição do paleorrelevo, utilizando-se como base a carta topográfica.

A técnica é eficiente para a reprodução de superfícies aplainadas elevadas e edifícios vulcânicos erodidos. Portanto, vem sendo utilizada para pesquisas de origem de relevos das regiões sob influência de movimentos verticais de falhas ativas (HUZITA e KASAMA, 1997 apud MOTOKI et al., 2008).

Fortes et al. (2010a, 2010b) têm utilizado os mapas de nivelamento de topos, para na interpretação do quadro evolutivo de bacias hidrográficas em zonas de bordas planálticas, submetidas a processos de recuo paralelo de encostas e deformações de caráter neotectônico.

Fortes et al. (2010a) passou a empregar ferramentas digitais na confecção dos mapas, porém seguindo as mesmas etapas descritas por Motoki et al., (2008): a) divisão do mapa topográfico em áreas quadradas por uma malha definida; b) marcação do ponto mais alto de cada área; c) confecção de um novo mapa topográfico somente com os pontos culminantes de cada área dividida

A escala da malha define o produto final a ser gerado. Mapas gerados com base em malhas mais finas, preenchem seletivamente as drenagens pequenas, simulando a superfície de aplainamento do passado relativamente mais recente. Por outro lado, mapas com base em malhas maiores simulam a paleosuperfície do passado mais remoto, porém de forma mais ambígua.

Apesar de se apresentar pouco confiável em termos cronológicos, a técnica permite reconstruir a paleopaisagem, permitindo importantes análises acerca da evolução do modelado do relevo.

Para possibilitar o uso do software na técnica de nivelamento de topos, necessita-se que os elementos de interesse sejam digitalizados: curvas de nível, pontos cotados e a hidrografia. Para isso as cartas topográficas da área foram 
Mapa de nivelamento de topos na análise da evolução geomorfológica da bacia hidrográfica do ribeirão Santo Inácio, Estado do Paraná

extraídas do site do ITCG (Instituto de Terras, Cartografia e Geociências $<w w w . i t c g . p r . g o v . b r>)$.

Após todos os elementos terem sido digitalizados seguiu-se a geração das grades triangular e quadrangular no software Spring. Simultaneamente no software AutoCAD foram geradas grades com quadrados de $1 \times 1 \mathrm{~km}$ e $0,5 \times 0,5 \mathrm{~km}$.

Prosseguiu-se ao processo de geração das novas isolinhas no software Surfer 8.0. Estes pontos possuem localização (valores $x$ e y) e altitude $(z)$ determinada. O software então gera novas curvas de nível a partir dos pontos de mesma altitude marcados anteriormente no software Spring 5.12.

A partir das curvas de nível, no próprio software Surfer 8.0, são gerados modelos numéricos de terreno (MNT) que possibilitam a visualização do paleorrelevo.

Para complementar as informações obtidas, foram elaborados perfis topográficos transversais e longitudinais da bacia hidrográfica. Estes perfis permitiram mostrar as nuanças do paleorrelevo e a comparação e compreensão mais detalhada das mudanças ocorridas no relevo.

O mapa geológico foi produzido a partir de produtos de sensoriamento remoto - imagens de satélite LANDSAT e de radar (SRTM - Shuttle Radar Topography Mission), que foram complementadas com checagem das informações em campo. Os dados obtidos com a análise litoestratigráfica foram inseridos nos modelos numéricos de terreno (MNT) permitindo visualizar e avaliar o comportamento do escoamento superficial e nível de dissecação do substrato rochoso.

Os trabalhos de campo foram feitos com o objetivo de checar as informações obtidas na etapa de interpretação das imagens, bem como realizar o registro fotográfico e descrição de perfis de intemperismo e afloramentos.

Foi elaborado também um estudo das características morfométricas da bacia a partir do software Global Mapper 11.0 que fornece dados relativos aos eixos da bacia, comprimento total das drenagens, área e perímetro da bacia e que permitiram calcular o Coeficiente de Compacidade (Kc), Índice de Circularidade, Fator de Forma (F) e a Densidade de Drenagem (DD). 
Mapa de nivelamento de topos na análise da evolução geomorfológica da bacia hidrográfica do ribeirão Santo Inácio, Estado do Paraná

\section{CONTEXTO AMBIENTAL REGIONAL}

A área de estudo está inserida na Bacia Sedimentar do Paraná, cujo relevo forma um conjunto de planaltos constituídos de rochas do Paleozóico e do Mesozóico, com mergulho regional suave para oeste e noroeste.

O Terceiro Planalto Paranaense, onde se encontra a área de trabalho, é representado por relevo uniforme, por vezes monótono, formado por colinas baixas, com altitudes que variam de 550 m, na região de Paranavaí, a 300 m nas margens do rio Paraná.

O relevo regional é formado por extensos espigões levemente ondulados, com vertentes convexas, longas e de baixa declividade. Apresenta baixa dissecação, exceto em determinados locais, onde a rede de drenagem está mais entalhada, ou nas cabeceiras dos principais rios. Nesses locais se desenvolvem relevos em forma de meia laranja, com vertentes convexas e desníveis que podem ultrapassar a $50 \mathrm{~m}$.

O clima da região, segundo a classificação de Köeppen e Geiger (1928) se enquadra como Cfa/Cwa. A posição subtropical do norte do Paraná condiciona um clima do tipo mesotérmico.

A precipitação média anual varia entre 1370 e 1460 mm na área da bacia hidrográfica do ribeirão Santo Inácio, com amplitude de mais de $1.000 \mathrm{~mm}$ entre anos chuvosos e secos. Durante os meses de inverno (Junho, Julho e Agosto), ocorre um período de estiagem, com volumes médios de precipitação abaixo dos $200 \mathrm{~mm}$, o que corresponde a pouco mais de 10\% do total das precipitações. Durante os meses de Dezembro e Fevereiro o volume de precipitações é maior, com média de cerca de $600 \mathrm{~mm}$, o que corresponde a cerca de $40 \%$ do total anual.

Segundo Camolezi (2010) a média das temperaturas máximas chega a 24,5ํ C na porção oeste da bacia hidrográfica do ribeirão Santo Inácio, enquanto a média das temperaturas mínimas atinge $14,1^{\circ} \mathrm{C}$ no quadrante sudeste da área de estudo. A temperatura média anual varia entre 19 e $20^{\circ} \mathrm{C}$, aumentando com a diminuição da latitude.

No noroeste e norte paranaense a formação vegetal predominante é a Floresta Estacional Semidecidual. Essa formação tem como característica principal a 
Mapa de nivelamento de topos na análise da evolução geomorfológica da bacia hidrográfica do ribeirão Santo Inácio, Estado do Paraná

perda de folhas em um período do ano, aspecto que se deve a diminuição da precipitação e da temperatura nos meses de inverno,

Caracteriza-se por apresentar vegetação densa, com poucas gramíneas e árvores com alturas de até $40 \mathrm{~m}$ (Macrofanerófitas). Não apresenta uma variedade muito grande de espécies de grande porte, cerca de 10 a 15 espécies se repetem na paisagem.

As espécies que identificam essa formação pertencem aos gêneros amazônicos Hymenaea (jatobá), Copaifera (óleo-vermelho), Peltophorum (Canafístula), Astronium, Handroanthus, Balfourodendron, entre outros (VELLOSO, 1992). O gênero que mais comum na área de estudo, entretanto é o Aspidosperma, e seu ecótipo Aspidosperma polyneuron, a peroba-rosa.

A cobertura vegetal natural foi quase que inteiramente devastada durante 0 processo de ocupação, ocorrido a partir da década de 1940, sendo a partir de então substituída pelas plantações de café e pastagens naturais, e posteriormente, pelas pastagens cultivadas. Após a erradicação dos cafezais na década de 1970, essas áreas foram substituídas pela cana-de-açúcar.

\section{CONTEXTO GEOLÓGICO E GEOMORFOLÓGICO DA BACIA HIDROGRÁFICA}

As unidades litoestratigráficas presentes na área estão representadas, da base para o topo, pelos Grupos São Bento, Caiuá e Bauru. O primeiro, do Cretáceo Inferior, é constituído por basaltos, que afloram muito localizadamente, junto à foz do ribeirão Santo Inácio (Fig. 2). Os basaltos são rochas ígneas afaníticas intrusivas, básicas, de coloração escura.

O Grupo Caiuá que constitui a sequência suprabasáltica do Cretáceo Superior formada predominantemente por arenitos finos a médios, está representado na área, da base para o topo, pelas formações Rio Paraná e Santo Anastácio (Fig. 2). O grupo Bauru é representado pela Formação Adamantina.

A Formação Rio Paraná é constituída predominantemente de arenitos de textura média, fina a muito fina, com grãos arredondados a bem arredondados e grau de seleção variando de pobre a muito bem selecionado. Apresenta alta 
Mapa de nivelamento de topos na análise da evolução geomorfológica da bacia hidrográfica do ribeirão Santo Inácio, Estado do Paraná

susceptibilidade à erosão devido à grande porcentagem da fração areia em sua constituição.

$\mathrm{Na}$ área de estudo a Formação Rio Paraná ocupa as médias e baixas vertentes (Fig. 2). A Formação Santo Anastácio aflora nas médias vertentes até os topos das colinas (Fig. 2), e é composta arenitos finos e muitos finos, quartzosos, com pequena quantidade de matriz silto-argilosa, originados em um ambiente arenoso extra-dunas (lençóis de areia) (FERNANDES e COIMBRA, 1994).

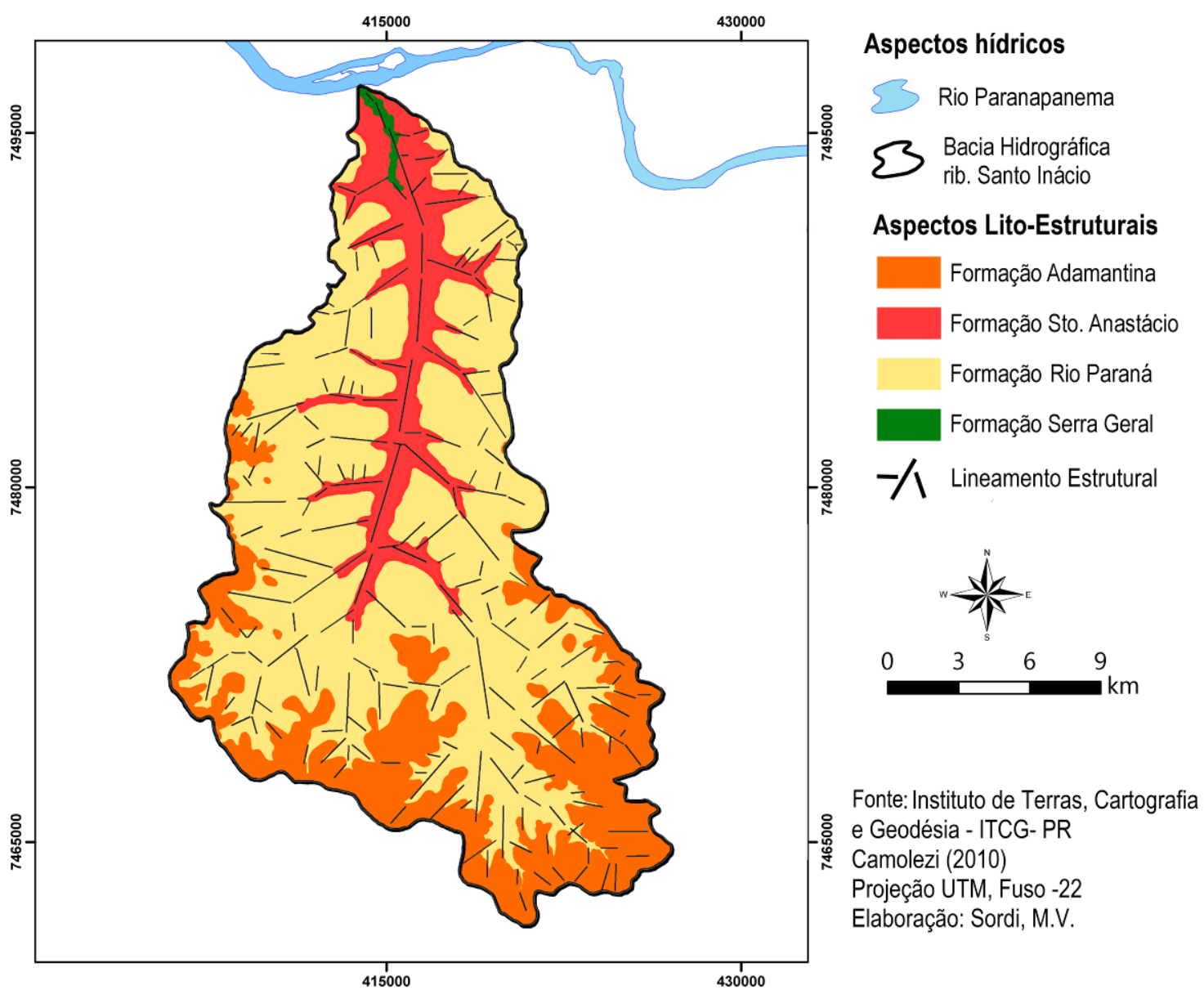

Figura 2: Mapa geológico contendo as litologias presentes na bacia hidrográfica do estudo.

A Formação Adamantina, do Grupo Bauru, encontra-se restrita nos topos mais elevados dos inteflúvios situados a sudeste (Fig. 2), formada por arenito fino a muito fino, alternado por bancos de lamitos e siltitos. A estrutura é geralmente maciça, mas com laminações cruzadas. Sua gênese é associada a um sistema 
Mapa de nivelamento de topos na análise da evolução geomorfológica da bacia hidrográfica do ribeirão Santo Inácio, Estado do Paraná

fluvial entrelaçado (braided) de planícies com lagoas efêmeras (FERNANDES e COIMBRA, 1994).

Essas litologias conferem ao relevo da bacia, um aspecto colinoso, com vertentes e topos convexos e declividades inferiores a $20 \%$. Depósitos quaternários restringem-se ao fundo dos vales e mais localizadamente nas baixas vertentes, com gênese aluvial e coluvial respectivamente. Na confluência do ribeirão Santo Inácio com o rio Paranapanema, depósitos de cascalhos polimíticos, representados por arenitos e em menor quantidade basaltos e calcedônias, evidenciam condições hidro-climatológicas mais severas no passado durante o Quaternário ou Terciário.

Os lineamentos estruturais estão relacionados, em sua maioria, a segmentos retilíneos ao longo dos cursos d'água (Figura 2). Eles se dispõem caoticamente, se destacando os segmentos de direção NE-SW e secundariamente de na direção EW.

Os solos que se desenvolvem sobre as rochas do Grupo Bauru apresentam textura média a arenosa e são muito friáveis. O substrato geológico associado ao clima da região, permitiu o desenvolvimento de solos profundos, formando coberturas areno-argilosas, com 2 a mais de $5 \mathrm{~m}$ de espessura, representativo do Latossolo Vermelho e que atestam a longevidade dos processos de alteração supérgena profunda.

O Latossolo Vermelho (LV) ocorre em áreas de relevo suave e ondulado, junto às altas vertentes e topos. Nas médias e baixas vertentes, e eventualmente nas altas vertentes pode ocorrer o Argissolo Vermelho (PV). Solos Litólicos e o Neossolo Quartzarênico $(R Q)$ podem ocorrer em áreas de maior declividade e no terço inferior das vertentes (GASPARETTO, 1999).

A bacia hidrográfica do ribeirão Santo Inácio apresenta uma área de 390,92 $\mathrm{km}^{2}$ e um perímetro de $110,07 \mathrm{~km}$. O quadro 1 apresenta os parâmetros morfométricos identificados para a bacia. 
Mapa de nivelamento de topos na análise da evolução geomorfológica da bacia hidrográfica do ribeirão Santo Inácio, Estado do Paraná

Quadro 1 - Características morfométricas da bacia do Ribeirão Santo Inácio.

\begin{tabular}{|l|l|}
\hline Características Físicas & Resultados \\
\hline Área de drenagem $\left(\mathrm{km}^{2}\right)$ & 390,92 \\
\hline Perímetro $(\mathrm{km})$ & 110,07 \\
\hline Comprimento Axial $(\mathrm{km})$ & 35,5 \\
\hline Coeficiente de compacidade $(\mathrm{Kc})$ & 1,56 \\
\hline Fator de forma $(\mathrm{F})$ & 0,17 \\
\hline Índice de circularidade $(\mathrm{IC})$ & 0,40 \\
\hline Índice de Sinuosidade $(\mathrm{Is})$ & 1,34 \\
\hline Altitude máxima $(\mathrm{m})$ & 527 \\
\hline Altitude mínima $(\mathrm{m})$ & 268 \\
\hline Amplitude altimétrica $(\mathrm{m})$ & 259 \\
\hline Ordem da bacia $($ Strahler 1957$)$ & 5 \\
\hline Densidade de Drenagem $\left(\mathrm{km} / \mathrm{km}^{2}\right)$ & 0,77 \\
\hline
\end{tabular}

Geomorfologicamente a bacia hidrográfica do ribeirão Santo Inácio obedece às características do relevo regional, com colinas baixas variando de $268 \mathrm{~m}$ próximo à confluência do ribeirão Santo Inácio com o rio Paranapanema até $527 \mathrm{~m}$ na parte sudeste, formando uma superfície suavemente inclinada para norte com desnível de $259 \mathrm{~m}$ distribuído ao longo de um eixo de $35,5 \mathrm{~km}$, que constitui o comprimento axial da bacia (Quadro 1).

A alta porosidade do substrato arenítico do Grupo Caiuá favorece o escoamento subsuperficial em detrimento do escoamento superficial o que pode ser constatado pela baixa densidade de drenagem de $0,77 \mathrm{~km} / \mathrm{km}^{2}$ (Quadro 1).

A bacia do ribeirão Santo Inácio apresenta forma alongada de direção N-S com ligeira inflexão, no terço montante de sudeste para noroeste. Essa característica alongada é evidenciada pelo Coeficiente de Compacidade $(\mathrm{Kc})$ de 1,56 e pelo Fator de Forma ( $F$ ) de 0,17 (Quadro 1). Esses dados de morfometria indicam uma taxa de escoamento superficial, executada pelas drenagens atuais, muito elevadas, o que dificulta a formação de enchentes. Esse dado também é comprovado pelo Índice de Circularidade (Ic) de 0,40 (Quadro 1).

\section{RESULTADOS E DISCUSSÃO}

Muitos autores estudaram as antigas superfícies de aplainamento existentes no Brasil durante o período Terciário e Quaternário, por vezes utilizando 
Mapa de nivelamento de topos na análise da evolução geomorfológica da bacia hidrográfica do ribeirão Santo Inácio, Estado do Paraná

denominações diferentes (peneplanos, pediplanos, pedimentos, etc.). Entre esses autores podemos citar De Martonne (1943; 1944), King (1956), Bigarella e Ab'Saber (1964), Bigarella e Mousinho (1965), Bigarella e Andrande (1965), Bigarella et al. (1965) e Justus (1985).

A partir de estudos realizados nos estados do Paraná e Santa Catarina, Bigarella e Ab'Saber (1964) propuseram uma nomenclatura para as superfícies de aplainamento denominadas de $\mathrm{Pd}_{3}, \mathrm{Pd}_{2}$ e $\mathrm{Pd}_{1}$. Os autores atribuíram a formação desses extensos patamares aplainados às variações paleoclimáticas da Era Cenozóica.

No Estado do Paraná foram reconhecidos quatro principais episódios de pediplanação: os pedimentos $\mathrm{Pd}_{3}, \mathrm{Pd}_{2}$ e $\mathrm{Pd}_{1}$ de Bigarella e Ab'Saber (1964) e o $\mathrm{Pd}_{0}$ descrito por Justus (1985) além de dois episódios de pedimentação $P_{2}$ e $P_{1}$. Esses eventos foram reconhecidos inclusive por trabalhos mais recentes, como os de Sallun et al., 2007; Palhares et al, 2011, Stefanello, 2011; Martins e Passos, 2012.

Estudos recentes abordando teorias de evolução das superfícies de aplainamento (PEULVAST e SALES, 2002; SALGADO, 2007) ressaltam a dificuldade de associação da evolução do relevo com modelos teóricos clássicos como os propostos pelos autores supracitados.

Na bacia hidrográfica do ribeirão Santo Inácio, os interflúvios mais elevados, cujas cotas chegam a $530 \mathrm{~m}$, possuem altimetrias correlatas àquelas descritas para o $\mathrm{Pd}_{1}$. O nível $\mathrm{Pd}_{0}$ referido como Pediplano Beira-Rio por Justus (1985), poderia ser associado as planícies baixas, junto a confluência com o rio Paranapanema, e cujas cotas chegam a $230 \mathrm{~m}$.

A despeito das evidências paleoclimáticas cíclicas com depósitos correlativos no Estado do Paraná, na área de estudo não foram identificados depósitos com características que evidenciem as de fases de pediplanação.

Paisani et al. (2008), a partir de estudos no sudoeste do Paraná e oeste de Santa Catarina, identificaram oito remanescentes de superfícies de aplainamento sobre rochas basálticas da Formação Serra Geral. A organização das superfícies aplainadas identificadas é sugerida pelos autores supramencionados como de origem tectônica. Contudo, se destaca a influência dos processos de etch por 
Mapa de nivelamento de topos na análise da evolução geomorfológica da bacia hidrográfica do ribeirão Santo Inácio, Estado do Paraná

rebaixamento e perda isovolumétrica do substrato, corroborando com as idéias de Wayland (1933) e Büdel (1957).

Os mapas de nivelamento de topos produzidos e o modelo digital do terreno, representativo da situação geomorfológica mais antiga (malha $1 \mathrm{~km}^{2}$ ), nos remete a identificação de altos e baixos estruturais, associados à intensa evolução geoquímica da paisagem, atestada pela forma das estruturas (arredondadas) e pelos espessos mantos de alteração existentes (Fig. 3).

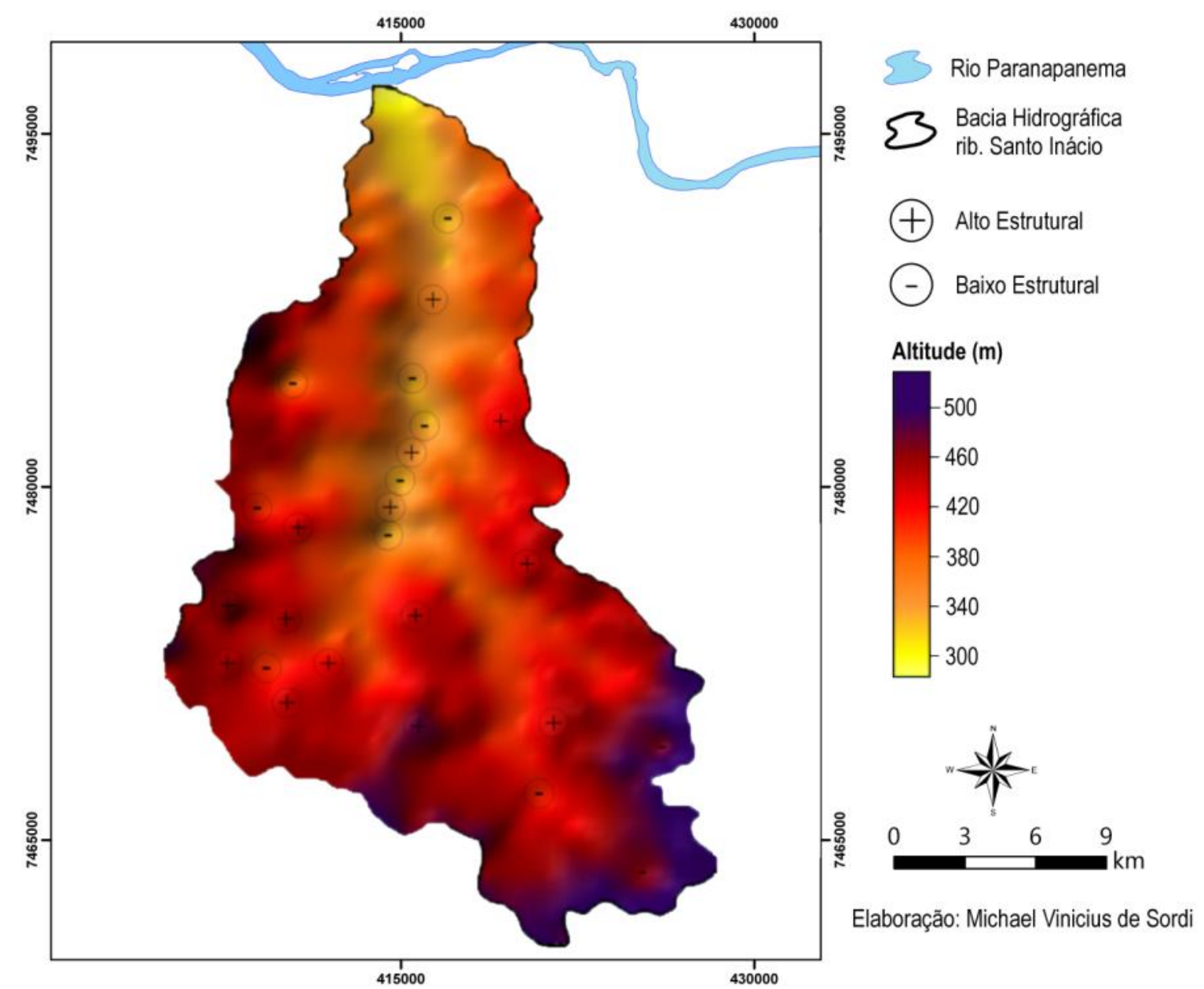

Figura 3: Mapa de Nivelamento de Topos, representativo de morfologia pré-atual, com os altos estruturais e baixos estruturais, na malha de $1 \mathrm{~km}^{2}$.

No mapa da figura 3 é evidenciada a participação do nível de base do rio Paranapanema até o terço inferior do vale do Ribeirão Santo Inácio, quando este é interrompido por um alto estrutural indicado nas figuras 3 e 4 , que isola uma área depressionária com aproximadamente $3,5 \mathrm{~km}$ de comprimento formando o que é 
Mapa de nivelamento de topos na análise da evolução geomorfológica da bacia hidrográfica do ribeirão Santo Inácio, Estado do Paraná

hoje o fundo do vale da bacia hidrográfica do ribeirão Santo Inácio. Outras depressões de forma circular podem ser observadas em zonas que atualmente correspondem às cabeceiras de drenagem dos principais afluentes do Santo Inácio (Figs. 4, 5 e 6).

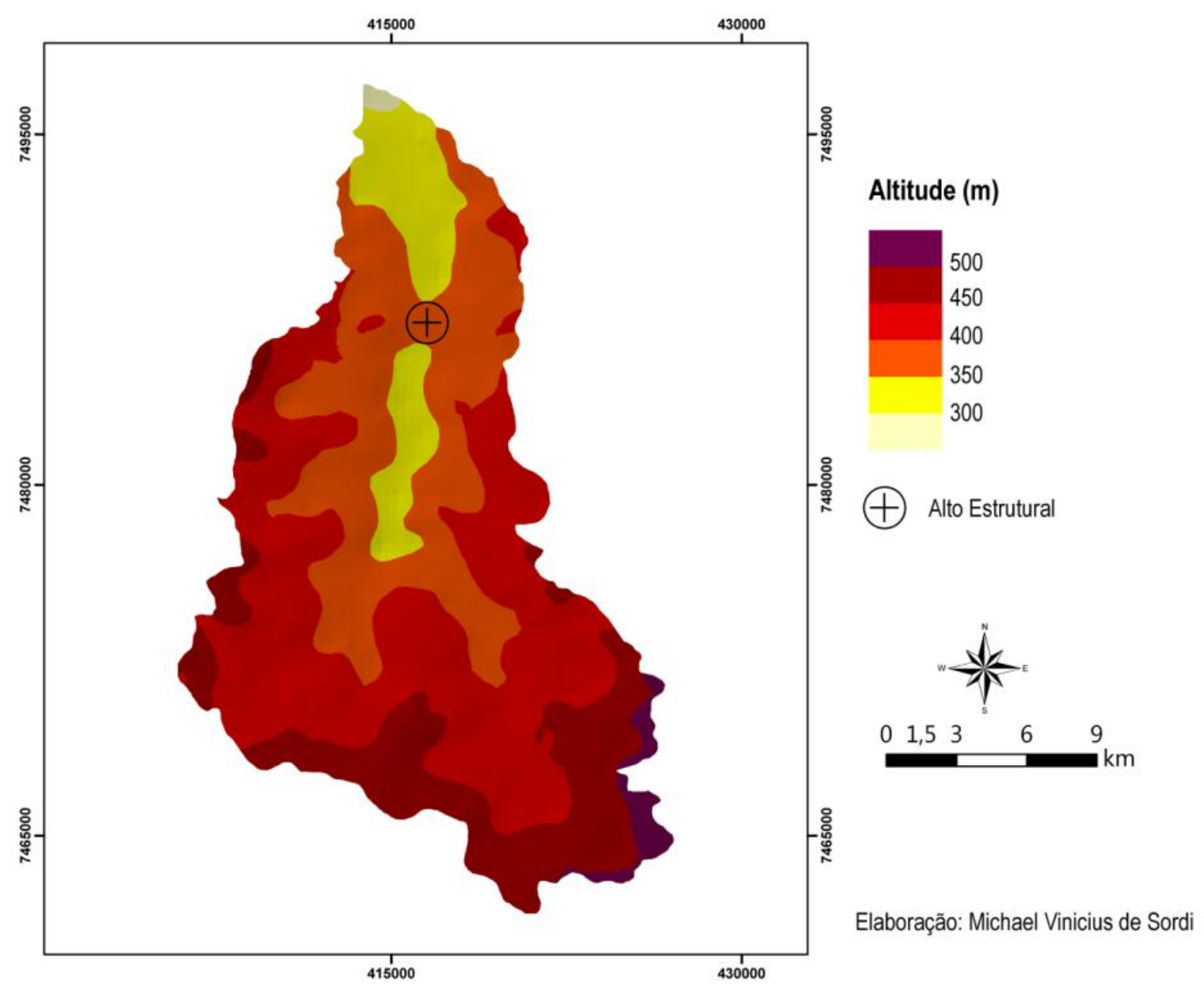

Figura 4: A área de influência do nível de base do Rio Paranapanema ocorre até a cota de $300 \mathrm{~m}$. A área indicada pelas flechas corresponde ao alto estrutural que divide as duas áreas baixas. 
Mapa de nivelamento de topos na análise da evolução geomorfológica da bacia hidrográfica do ribeirão Santo Inácio, Estado do Paraná
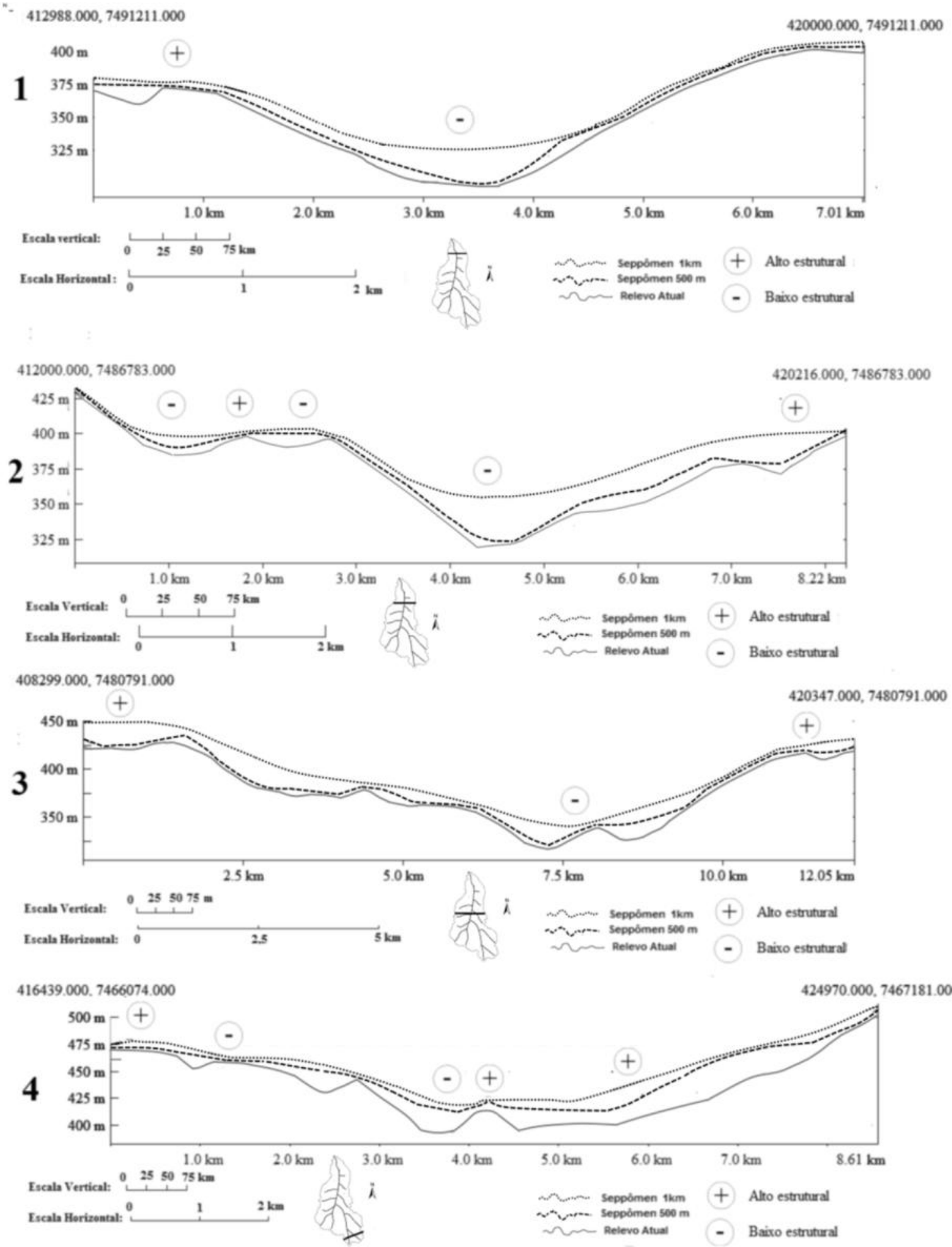

Figura 5: Perfis topográficos com sobreposição da topografia extraída do mapa de Nivelamento de Topos. 
Mapa de nivelamento de topos na análise da evolução geomorfológica da bacia hidrográfica do ribeirão Santo Inácio, Estado do Paraná

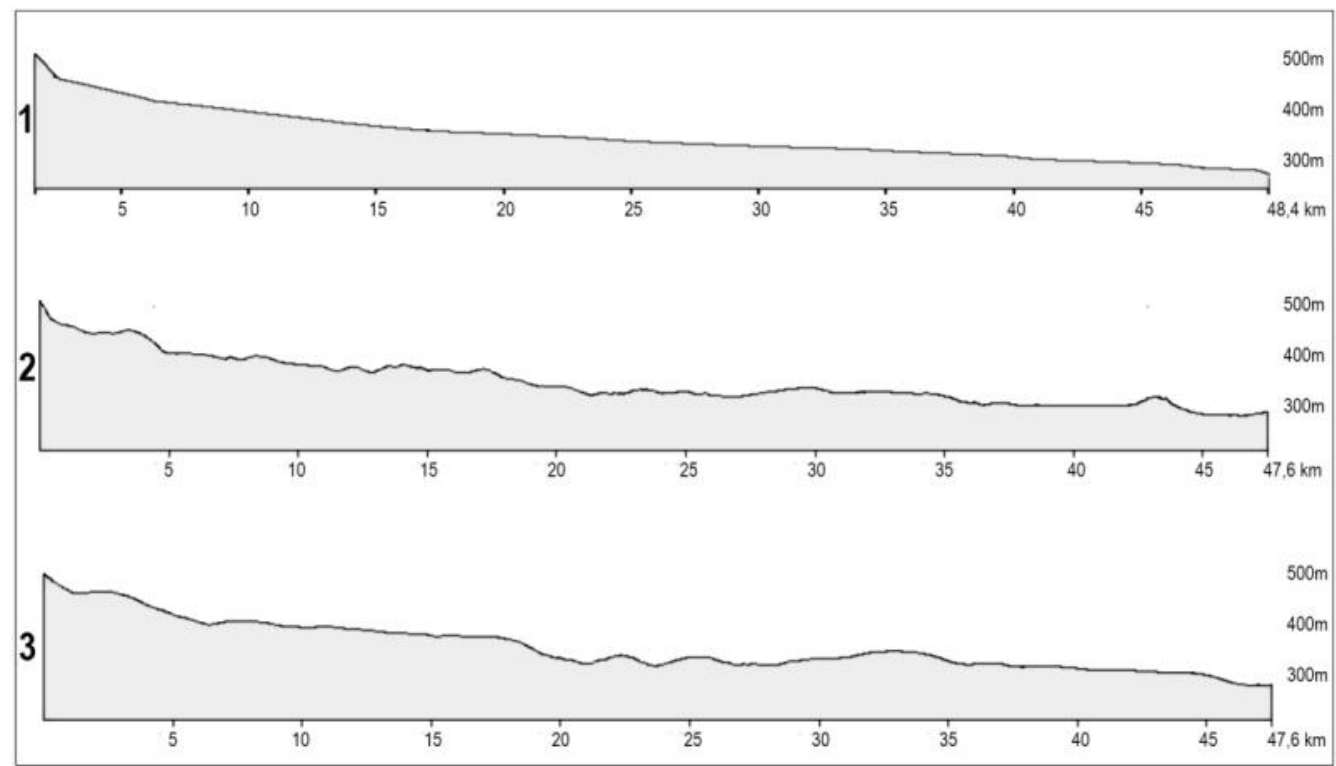

Figura 6: Perfis Topográficos Longitudinais. 1 - Superfície obtida com a malha de $1 \mathrm{~km} ; 2$ - Superfície obtida com a malha de $0,5 \mathrm{~km} ; 3$ - topografia atual.

A influência dos processos geoquímicos na evolução da paisagem é evidenciada por espessos mantos de alteração, que constituem principalmente os Latossolos, e cujas espessuras podem chegar a mais de $5 \mathrm{~m}$ (Fig. 7).

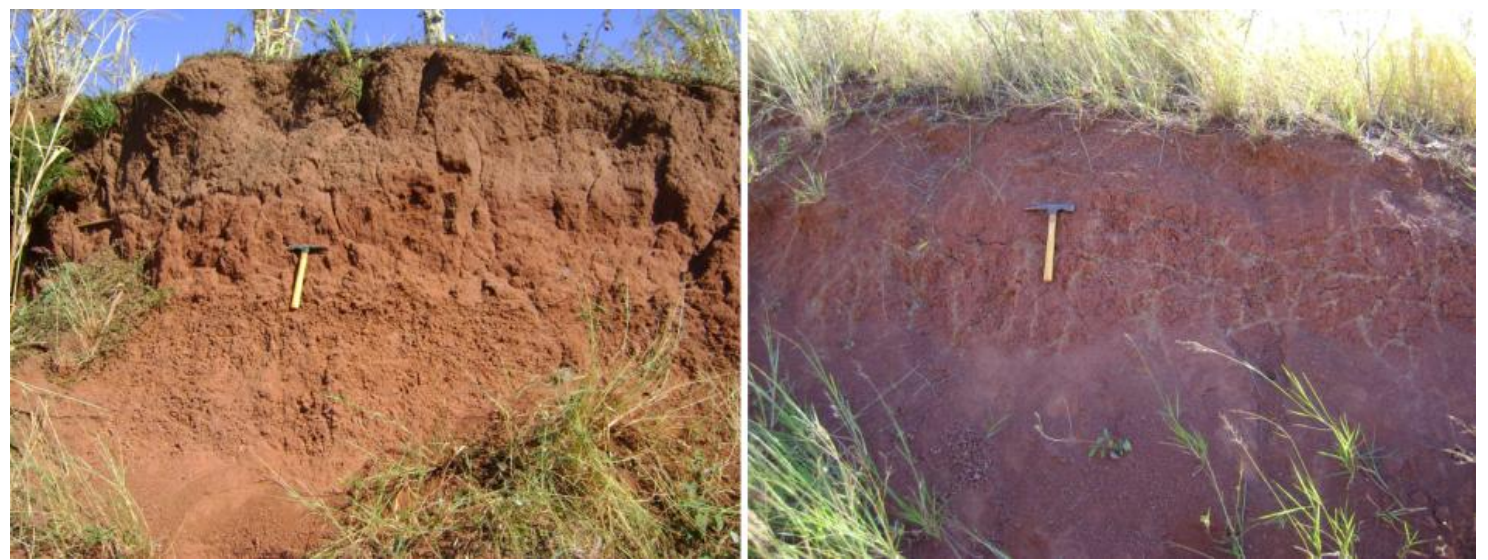

Figura 7: Regolitos areno-argilosos associados à alteração supérgena profunda.

Estudos realizados por Gasparetto (1999) e Gasparetto et al., (2010), a partir descrições macro e micromorfológicas dos solos que compõem o sistema pedológico LV-PV-RQ, nas bacias de primeira ordem, reforçam a idéia de que a paisagem evoluiu a partir do desgaste geoquímico. Segundo o autor, nas topossequências estudadas, no sopé da vertente instala-se um sistema de 
Mapa de nivelamento de topos na análise da evolução geomorfológica da bacia hidrográfica do ribeirão Santo Inácio, Estado do Paraná

transformação remontante, em que se dá a separação do plasma em relação ao esqueleto, favorecendo o acúmulo relativo deste último e tendo como conseqüência o aumento da espessura do volume arenoso superficial.

A transição supramencionada considera uma frente de transformação, com evacuação do plasma e acumulação relativa do esqueleto. As frações mais finas do plasma (formadas por soluções e elementos dissolvidos) são evacuadas da bacia pelas drenagens (Figs. 8 e 9). Nesse caso, a evolução da cobertura pedológica é acompanhada por um rebaixamento da superfície topográfica, correspondente às perdas da matéria que acompanham as transformações dos volumes em profundidade e na lateralidade.

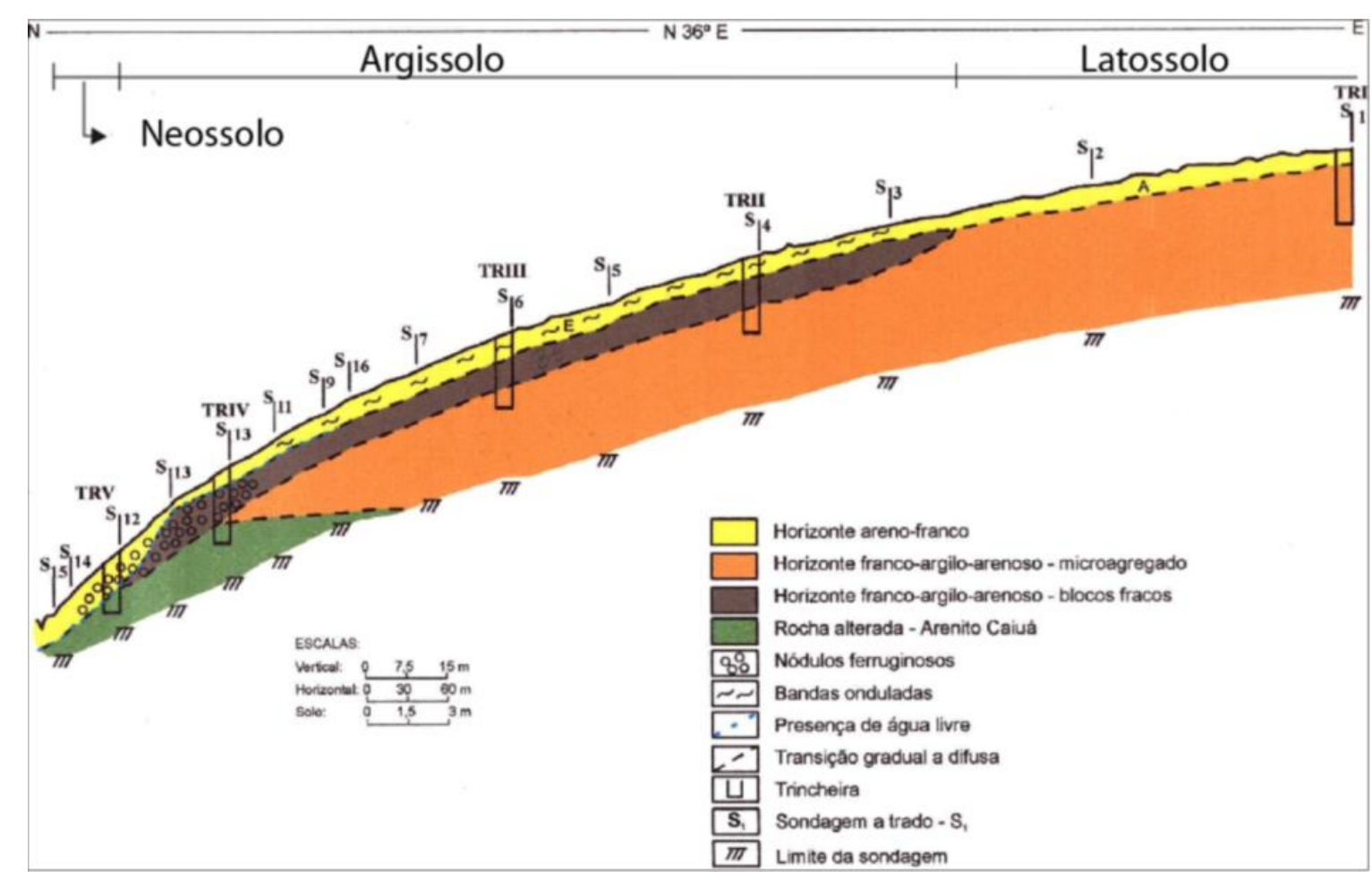

Figura 8: Topossequência Três Leões em Cianorte, evidenciando perdas de matéria que acompanham o rebaixamento da superfície topográfica (GASPARETTO 1999). 
Mapa de nivelamento de topos na análise da evolução geomorfológica da bacia hidrográfica do ribeirão Santo Inácio, Estado do Paraná

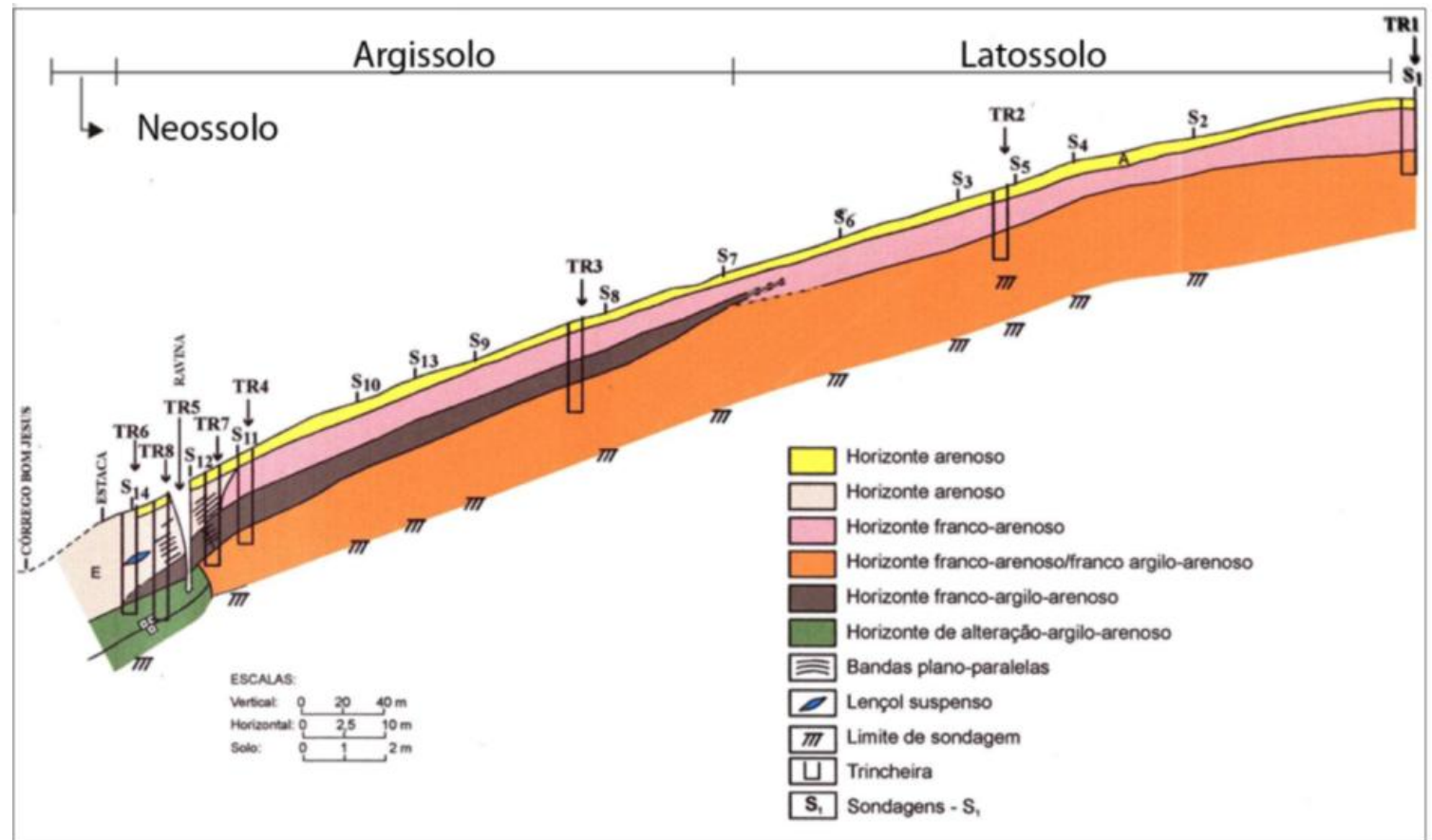

Figura 9: Topossequência Bom Jesus, em Cidade Gaúcha (MARTINS et al. 1998 apud GASPARETTO 1999), evidenciando perdas de matéria que acompanham o rebaixamento da superfície topográfica por processos de erosão remontante.

Ainda segundo Gasparetto (1999) e Gasparetto et al., (2010), as modificações da cobertura pedológica são mais evidentes no sopé da vertente do que no topo (Figs. 8 e 9), embora essas transformações progridam em direção a montante, podendo inclusive abranger toda a vertente, fato também presente na bacia de Santo Inácio ao longo de muitos dos afluentes do curso principal.

Esses indícios corroboram os produtos cartográficos gerados pela técnica de nivelamento de topos. Estes evidenciam a evolução geoquímica da paisagem a partir do rompimento de altos estruturais. Os altos estruturais representariam zonas preferenciais de perda de minerais por escoamento subsuperficial, o que, em última análise conduziria a um aplainamento por rebaixamento isovolumétrico do relevo, conforme observado também por Paisani et al. (2008), acompanhando um processo de erosão remontante regional, como sugerido por Gasparetto e Gasparetto et al., (op. cit.).

As figuras 10 e 11 sugerem que o canal principal do rio Santo Inácio teve seu desenvolvimento associado ao rompimento do alto estrutural próximo ao rio 
Mapa de nivelamento de topos na análise da evolução geomorfológica da bacia hidrográfica do ribeirão Santo Inácio, Estado do Paraná

Paranapema. As nascentes de muitos afluentes estão associadas a baixos estruturais, que progressivamente deram origem a cursos d'água intermitentes.

O nível de base do Rio Paranapanema passa a ter maior importância na medida em que as zonas depressionárias são conectadas, permitindo a dissecação mais vigorosa dos talvegues (Fig. 10A e 11A). A dissecação do relevo promovida pela alteração geoquímica associada aos controles exercidos pelo nível de base do Paranapanema alcançou até $35 \mathrm{~m}$ (Fig. 10A) na parte jusante.

As zonas associadas aos baixos estruturais podem ser evidenciadas na figura 5 , nos perfis 1 a 4 , junto as principais cabeceiras de drenagem, que mostram rebaixamento variando da ordem de 15 a $25 \mathrm{~m}$ de profundidade.

O perfil topográfico longitudinal ilustra as características já verificadas nos MNT. O leito do rio principal se apresentava descontinuo (Fig. 11C), não mostrando características de um curso de água perene.

O leito do rio, como já observado, possuía altos e baixos estruturais ao longo do seu curso os quais ao se romperem permitiram a constituição do leito principal do ribeirão Santo Inácio.

No perfil referente ao mapa elaborado com malha de $1 \mathrm{~km}$, pode se notar altos estruturais alongados e aplainados sem grande diferenciação altimétrica entre baixos e altos estruturais (Fig. 11C).

No perfil relativo ao mapa de malha $0,5 \mathrm{~km}$ (Fig. 11B) os altos e baixos estruturais tem menores dimensões e possuem freqüentes intercalações. Alguns altos estruturais de maiores proporções se destacam na paisagem, mas são raros. 
Mapa de nivelamento de topos na análise da evolução geomorfológica da bacia hidrográfica do ribeirão Santo Inácio, Estado do Paraná

A) SEPPÔMEN $1 K^{2}$

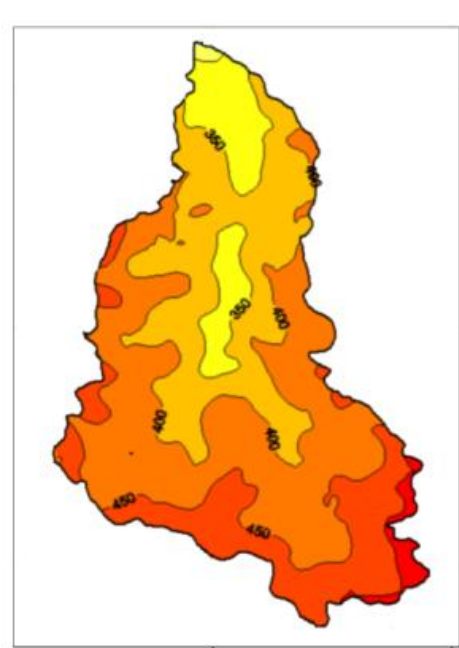

PASSADO

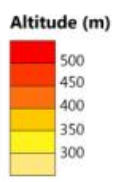

B) SEPPÔMEN $0,25 \mathrm{KM}^{2}$
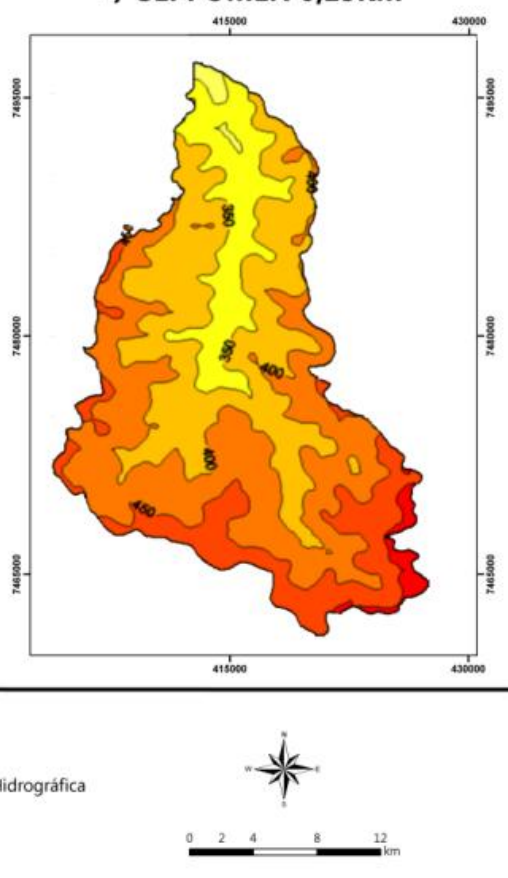

C) MODELADO ATUAL

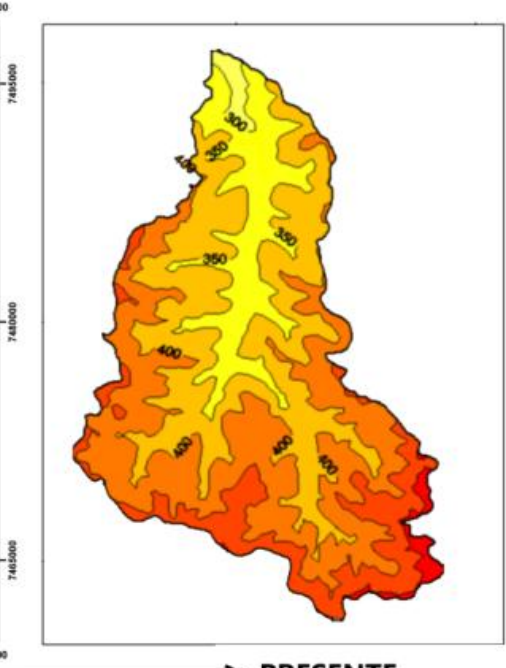

PRESENTE

Fonte:
Cartas Topográficas de Santo Inácio - SF.22-Y- - B-V-1 Carta Topográfica de Colorado - SF.22-Y.B-V-V-3 Carta Topográfica de Escala: 1:50.000

Figura 10: Mapas Hipsométricos elaborados a partir do mapa de Seppômen (B e C) e carta topográficas $(A)$. O mapa $A$ se refere a um período mais remoto, construído a partir da malha $1 \mathrm{~km}$, já o mapa $B$ se refere a uma época mais recente (malha 0,5).A mapa $C$ se refere ao modelado atual

A) SEPPÔMEN $1 K^{2}$

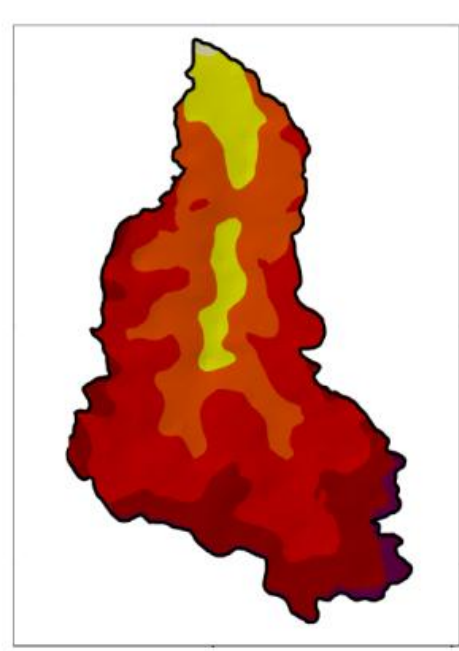

PASSADO
B) SEPPÔMEN 0,25KM²
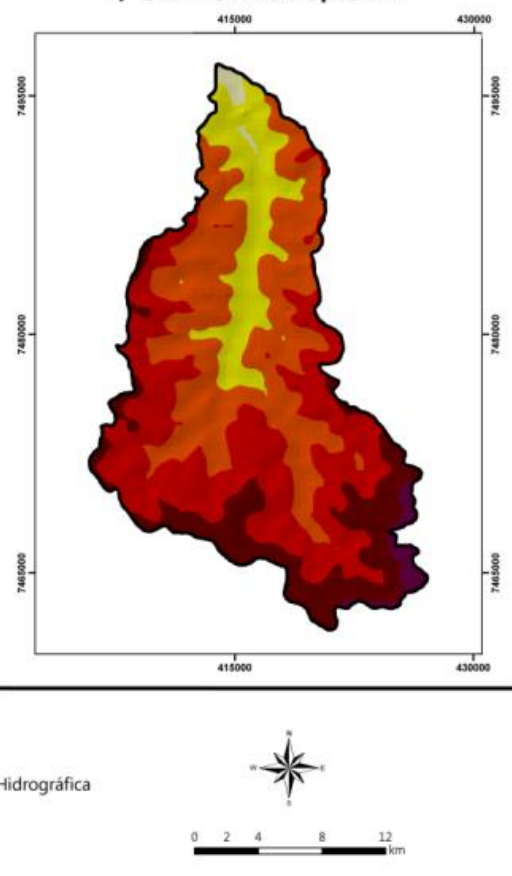

C) MODELADO ATUAL

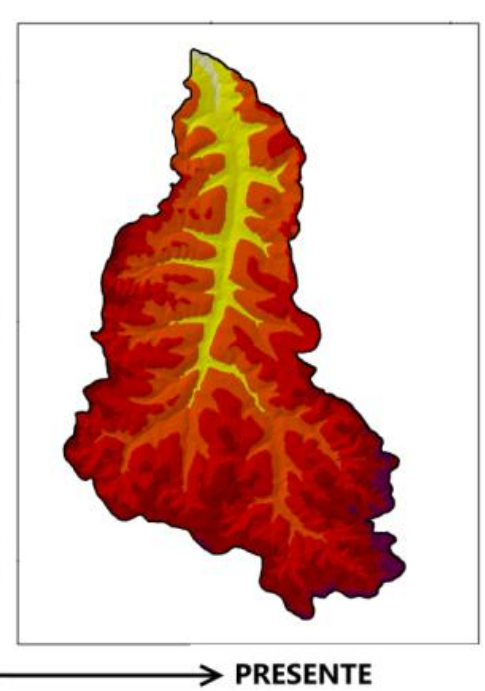

Fonte: Carta Topográfica de Colorado - $5 F 22-Y \cdot-8-Y \cdot 3$ Carta Topográfica de Centenário do Sul - SF-22-Y-B-V-4

Escala: 1:50.000

Figura 11: Modelos numéricos de terreno. Na figura $C$ temos o mapa do modelado atual do relevo, no B o mapa retrata um período próximo ao atual enquanto no $A$ é retratado o modelado de um período mais antigo. 
Mapa de nivelamento de topos na análise da evolução geomorfológica da bacia hidrográfica do ribeirão Santo Inácio, Estado do Paraná

\section{CONCLUSÕES}

Com bases nos estudos realizados foi possível constatar que os mapas de nivelamento de topos, quando analisados em conjunto com dados de campo e bibliografia pertinente, podem ser de grande utilidade para o diagnóstico da evolução dos modelados de relevo. Embora não seja possível estabelecer uma cronologia para os eventos descritos, pode-se constatar que a superfície aplainada, visualizada nas figuras $10 \mathrm{C}$ e $11 \mathrm{C}$, teria se desenvolvido posteriormente ao pediplano $\mathrm{Pd}_{1}$, descrito por Bigarella e Andrade (1965), podendo nesse caso ser relacionado ao pediplano $\mathrm{Pd}_{0}$ descrito por Justus (1985). Entretanto, a ausência de depósitos correlativos, estruturas rúpteis, não nos permite fazer uma associação mais consistente à essa superfície, principalmente porque as evidências encontradas in situ apontam para um aplainamento desenvolvido sob vigência de climas úmidos, onde a evolução geoquímica é o principal processo modelador da paisagem.

A despeito de interpretações geoquímicas para evolução do relevo da bacia do ribeirão Santo Inácio, outros estudos realizados por Fortes et al. (2010a,b), que empregaram mapas de nivelamento de topos na borda planáltica paranaense, registraram forte influência de condicionantes paleoclimáticas, associadas a elementos estruturais. Estes fatos permitem deduzir que os mapas de nivelamento de topos podem ser empregados em diferentes contextos geomorfológicos, geológicos e climáticos, havendo sempre a necessidade de complementação das informações com dados de campo e suporte bibliográfico adequado.

\section{REFERÊNCIAS}

AB'SABER, A.N. Espaços ocupados pela expansão dos climas secos na América do Sul por ocasião dos períodos glaciais quaternários. IGEOG-USP- Série Paleoclimas, São Paulo, v. 3, p. 1-19, 1977.

BIGARELLA, J.J.; ANDRADE, G.O. Contribution to the study of the Brazilian quaternary. In: WRIGHT, J.H.E. e FREY D.G. International studies on the Quaternary. Geological Society of America, v. 84 (special paper), p. 443-451. 1965. 
Mapa de nivelamento de topos na análise da evolução geomorfológica da bacia hidrográfica do ribeirão Santo Inácio, Estado do Paraná

BIGARELLA, J.J.; AB'SABER, A.N. Palaeogeographische und Paleoklimatische Aspekte der Kaenozaikus in Sudbrasilien. Zeitschrift für Geomorphologie, Stuttgart , v. 8, n.3, p. 286-312. 1964.

BIGARELLA, J.J.; MOUSINHO, M.R. Considerações a respeito dos Terraços Fluviais, Rampas de Colúvio e Várzeas. Boletim Paranaense de Geografia, Curitiba, n.16/17, p. 153-196, 1965.

BIGARELLA, J.J.; MOUSINHO, M.R.; SILVA, J.X. Pediplanos, pedimentos e seus depósitos correlativos no Brasil. Boletim Paranaense de Geografia, Curitiba, n.16/17, p. 117-151, 1965.

BÜDEL, J. Die doppeleten Einebnungsflächen in den feuchten Tropen. Zeitschrift für Geomorphologie, Stuttgart, n. 1, v.1, p. 201-288, 1957.

DE MARTONNE, E. Problemas morfológicos do Brasil Tropical Atlântico - Parte I. Revista Brasileira de Geografia, Rio de Janeiro, v. 5, n. 4, p 523-550, 1943.

DE MARTONNE, E. Problemas morfológicos do Brasil Tropical Atlântico - Parte II. Revista Brasileira de Geografia, Rio de Janeiro, v. 6, n. 2, p 155-178, 1944.

FERNANDES, L.A.; COIMBRA, A.M. O Grupo Caiuá (Ks): Revisão Estratigráfica e Contexto Deposicional. Revista Brasileira de Geociências, v. 24, n. 3, p. 164-176, 1994.

FORTES, E.; COUTO, E.V.; SORDI, M.V.; MARQUES, A.J. Evolução Geomorfológica da Área Abrangida pela Carta de Faxinal - PR: com base em Mapas de Nivelamento de Topos. In: SANTIL, F.L.P.; SILVEIRA, H.; SOUZA, M.L.; SANTOS, F.R. (Org.). Recursos Tecnológicos Aplicados a Cartografia. Maringá, Ed. Sthampa Gráfica e Editora, p.134-150. 2010.

FORTES, E.; OLIVEIRA, S.; VOLKMER, S. Aplicações da técnica de seppômen na análise Paleocimática e morfoestrutural: o caso da bacia Hidrográfica do Rio São Pedro - Faxinal, PR. In: II SEMINÁRIO IBERO AMERICANO DE GEOGRAFIA FÍSICA/ VI SEMINÁRIO LATINO AMERICANO DE GEOGRAFIA FíSICA, Anais Coimbra, Portugal, p.1-12. 2010.

GASPARETTO, N.V.L.; MARTINS, V.M.; CASTRO, S.S.; SANTOS, M.L. $\mathrm{O}$ sistema pedológico LV-PV-Q e sua relação com a erosão na região noroeste do e 
Mapa de nivelamento de topos na análise da evolução geomorfológica da bacia hidrográfica do ribeirão Santo Inácio, Estado do Paraná

stado do paraná-BR. In: CONGRESSO NACIONAL DE GEOMORFOLOGIA, 5, 2010, Actas..., Porto, Portugal, p. 169-174. 2010.

GASPARETTO, N.V.L. As formações superficiais do noroeste do Paraná e sua relação com o Arenito Caiuá. Tese de Doutorado, Programa de Pós-graduação em Geologia Sedimentar, Instituto de Geociências, Universidade de São Paulo. São Paulo. 1999.

JUSTUS, J.O. Subsídios para interpretação morfogenética através da utilização de imagens de radar. Dissertação de Mestrado, Universidade Federal da Bahia, Salvador. 1985.

KING, L.C. A Geomorfologia do Brasil Oriental. Revista Brasileira de Geografia, Rio de Janeiro, v. 18, n. 2, p. 147-265, 1956.

KÖPPEN, W.P.; GEIGER, R.O.R.W. Klimate der Erde. Verlag Justus Perthes, Gotha. Wall-map $150 \mathrm{~cm} \times 200 \mathrm{~cm} .1928$.

MAACK, R. Notas preliminares sobre o clima, solos e vegetação do Estado do Paraná. Arquivos de Biologia e Tecnologia, Curitiba, v.3, n.8, p.99-200, 1948.

MAACK, R. Geografia Física do Estado do Paraná. Curitiba: Universidade Federal do Paraná e Instituto de Biologia e Pesquisa Tecnológica, 1968.

MARTINS, T.D.; PASSOS, E. Superfícies Aplainadas na Bacia Hidrográfica no Altíssimo Rio Tibagi - PR. ACTA Geográfica, (Boa Vista), v.11, n.6, p. 133-152, 2012.

MARTINS, V.M.; CASTRO, S.S.; CUNHA, J.E.; NÓBREGA, M.T.; GASPARETTO, N.V.L. Relação entre o modelado e a cobertura pedológica na vertente direita do córrego Bom Jesus em Cidade Gaúcha - PR. Geosul, Florianópolis, v.14 n.27(Edição Especial), p. 511-514, 1998.

MOTOKI, A.G.; PETRAKIS, H.; SICHEL, S.E.; CARDOSO, C.E.; MELO, R.C.; SOARES, R.; MOTOKI, K.F. Origem dos relevos do maciço sienítico do Mendanha, RJ, com base nas análises geomorfológicas e sua relação com a hipótese do vulcão de nova Iguaçu. Geociências,UNESP, v.27 n.1, p.97-113, 2008. 
Mapa de nivelamento de topos na análise da evolução geomorfológica da bacia hidrográfica do ribeirão Santo Inácio, Estado do Paraná

PALHARES, J.M.; PASSOS, E.; SILVA, A.J. Morfoestrutura e Morfoescultura: Superfícies Aplanadas do Planalto de Guarapuava - Pr. Ciência Geográfica (Bauru), v. 15, n. 1, 2011.

PAISANI, J.C.; PONTELLI, M.E.; ANDRES, J. Superfícies aplainadas em zona Morfoclimática subtropical úmida no planalto basáltico da bacia do Paraná (SW Paraná /NW Santa Catarina): Primeira Aproximação. Geociências,UNESP, Rio Claro, v. 27, n. 4, p. 541-553, 2008.

PEUVAST, J.P.; SALES, V.C. Aplainamento e geodinâmica: revisitando um problema clássico em geomorfologia. Mercator (UFC), v. 1, n. 1, p. 113-150, 2002.

SALGADO, A.A.R. Superfícies de Aplainamento: Antigos paradigmas revistos pela ótica dos novos conhecimentos geomorfológicos. Geografias (UFMG), v. 3, n. 1, p. 64-78, 2007.

SALLUN, A.E.M.; SUGUIO, K.; SALLUN-FILHO, W. Geoprocessamento para Cartografia do Alogrupo Alto Rio Paraná (SP, PR e MS). Revista Brasileira de Cartografia, v.59, n. 3,p. 289-299, 2007.

STEFANELLO, A.C. Estudo da ocorrência de superfícies de aplanamento em transectos no setor oriental do Estado do Paraná. Tese (doutorado). Programa de Pós-Graduação em Geografia, Universidade Federal do Paraná, Curitiba, 171 p., 2011.

VELOSO, H.P.; OLIVEIRA FILHO, L.C.; VAZ, A.M.S.F; LIMA, M.P.M.; MARQUETE, R.; BRAZÃO, J.E.M. (Org.) Manual Técnico da Vegetação Brasileira. IBGE, Rio de Janeiro, 92 p., 1992.

WAYLAND, E.J. Peneplains and some other erosional platforms. Annual Report and Bulletin, Protectorate of Uganda Geological Survival Department of Mines, Kampala v.1, n.1, p. 77-79. 1933. 